\title{
PENGARUH PEMBERIAN PAKAN TAMBAHAN YANG BERBEDA TERHADAP PERTUMBUHAN LOBSTER AIR TAWAR (Cherax quadricarinatus)
}

\author{
Fitriana santia Hanisah $^{\mathrm{b}}$, Iwan Hasri ${ }^{\mathrm{c}}$, Agus Putra $\mathbf{A S}^{\mathrm{a}^{*}}$ \\ aProgram Studi Akuakultur, Fakultas Pertanian, Universitas Samudra, Indonesia

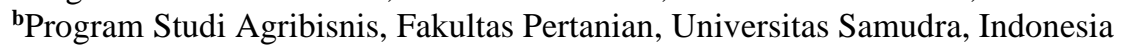 \\ 'Balai Benih Ikan Lukup Badak, Aceh Tengah, Indonesia \\ *Koresponden penulis: agus.putra.samad@gmail.com
}

\begin{abstract}
Abstrak
Lobster air tawar (Cherax quadricarinatus) merupakan kelompok crustacea yang hidup di perairan tawar. Lobster ini pada umumnya memiliki potensi yang bagus untuk dibudidayakan. Penelitian ini bertujuan untuk mengetahui jenis pakan tambahan yang tepat untuk pertumbuhan lobster air tawar. Metode eksperimen yang digunakan adalahRancangan Acak Lengkap 4 perlakuan dan 3 pengulangan yaitu PL (kontrol), PW (pellet dan wortel), PK (pellet dan kentang) dan PJ (pellet dan ubi jalar putih). Lobster air tawar yang digunakan dalam penelitian ini yaitu ukuran $5-7 \mathrm{~cm}$ dan berat $6-8 \mathrm{~g}$. Hasil penelitian ini menunjukkan bahwa pemberian pakan tambahan mempengaruhi peningkatan pertumbuhan Lobster air tawar, dimana pertambahan bobot mutlak (PBM), laju pertumbuhan harian (LPH) dan laju pertumbuhan berat (WG) yang terbaik di perlakuan PW yaitu $(2,21 \pm 0,06),(1,05 \pm 0,03)$ dan $(34,40 \pm 1,15)$ serta pertambahan panjang mutlak (PPM) tertinggi di perlakuan PJ yaitu $(0,44 \pm 0,02)$. Hal ini menjelaskan bahwa pakan tambahan wortel adalah pakan dengan kombinasi terbaik sehingga dapat mengoptimalkan pertumbuhan lobster air tawar.
\end{abstract}

Kata Kunci: Lobster air tawar, pakan tambahan, pertumbuhan, wortel

\begin{abstract}
Freshwater lobster (Cherax quadricarinatus) is a group of crustaceans that live in freshwater. This lobster has a good potential to be cultivated. This research was carried out to investigate the use of supplementary feeding to grow out the freshwater lobster. The research design used completely randomized design consisting of 4 treatments and 3 repetitions, namely PL (control), PW (pellets and carrots), PK (pellets and potatoes) and PJ (pellets and white sweet potatoes). The freshwater lobster used in this study was $5-7 \mathrm{~cm}$ in size and $6-8 \mathrm{~g}$ in weight. The results of this study indicated that supplementary feeding affects the increase in the growth of freshwater lobster, where the weight gain, daily growth rate and weight growth percentage were $(2.21 \pm 0.06),(1.05 \pm 0.03)$ and $(34.40 \pm 1.15)$ in PW treatment, respectively. The highest length gain was in the PJ treatment $(0.44 \pm 0.02)$. This study explained that carrot supplementary feed was the best combination to optimize the growth of freshwater lobster.
\end{abstract}

Keywords: Carrots, feed, growth, freshwater lobster

\section{PENDAHULUAN}

Lobster air tawar (Cherax quadricarinatus) merupakan kelompok crustacea yang hidup di perairan tawar. Lobster ini umumnya memiliki potensi yang sangat bagus untuk dikembangkan. selain mudah dibudidayakan, lobster air tawar termasuk jenis hewan omnivora yang tahan terhadap serangan penyakit dan memiliki fekunditas tinggi sehingga sangat cocok untuk dikembangkan secara luas dan bermanfaat secara ekonomi. Cherax quadricarinatus belum banyak dibudidayakan di Indonesia, hal ini wajar 
Dalam budidaya lobster air tawar, pakan memegang peranan sangat penting karena pakan dapat menghabiskan 40-50\% dari total biaya produksi [5]. Oleh sebab itu, pengetahuan tentang kebutuhan pakan, jenis dan komposisinya sangatlah diperlukan.

Untuk mengetahui jenis pakan yang sesuai agar mempercepat peningkatan pertumbuhan lobster air tawar, maka perlu dilakukan suatu penelitian dengan pemberian jenis pakan yang berbeda. Oleh sebab itu, Penelitian ini bertujuan untuk mengetahui pengaruh pemberian pakan tambahan yang berbeda terhadap pertumbuhan lobster air tawar (Cherax quadricarinatus). Sehingga diharapkan hasil penelitian dapat memberikan data ataupun informasi kepada para pembudidaya tentang jenis pakan tambahan dan cara pemberian pakan yang dapat mengoptimalkan pertumbuhan lobster air tawar.

\section{MATERI DAN METODE}

\section{Tempat dan Waktu Penelitian}

Penelitian ini dilaksanakan di Balai Benih Ikan (BBI) Lukup Badak, Kecamatan Pegasing, Kabupaten Aceh Tengah.

\section{Metode Penelitian}

Metode yang digunakan pada penelitian inii adalah eksperimental dengan Rancangan Acak Lengkap, dengan 4 perlakuan yang berbeda dan dilakukan pengulangan sebanyak 3 kali disetiap perlakuan untuk melihat pengaruhnya terhadap pertumbuhan lobster air tawar. Adapun perlakuan yang digunakan dalam penelitian ini adalah sebagai berikut: PL (pemberian pakan pellet (kontrol); PW (pemberian pakan pellet + pakan tambahan wortel); PK (pemberian pakan pellet + pakan tambahan kentang); PJ (pemberian pakan pellet + pakan tambahan ubi jalar putih).

\section{Persiapan wadah}

Wadah pemeliharaan lobster air tawar menggunakan sterofom berukuran panjang, lebar dan tinggi masing-masing 75 x $42 \times 38$. Sebelum benih lobster air tawar dipelihara maka terlebih dahulu dipersiapkan alat dan bahan yang akan digunakan selama penelitian. Persiapan wadah dimulai dengan mencuci sterofom menggunakan air bersih, kemudian sterofom dijemur dahulu agar kering dan baru dilakukan pengisian air dengan ketinggian 15 $\mathrm{cm}$ dari volume sterofom yaitu 119,7 liter. Kemudian aerator diletakkan pada setiap sterofom untuk menjaga ketersediaan oksigen dalam air selamapemeliharaan.

\section{Persiapan Hewan Uji}

Lobster air tawar diperoleh dari tangkapan alam, Danau Laut Tawar, Takengon, Aceh Tengah. Penebaran benih dilakukan pada pagi hari untuk menghindari terjadinya stress. Hewan uji ditebar didalam sterofom berukuran 5-6 $\mathrm{cm}$ dan berat 6-8 $\mathrm{g}$. Jumlah lobster air tawar yang digunakan adalah sebanyak 80 ekor dengan jumlah padat tebar 5 ekor/wadah. Penebaran dilakukan dengan cara aklimatisasi terlebih dahulu selama 7 hari dengan tujuan agar lobster air tawar beradaptasi dengan kondisi air yang baru. Selama proses aklimatisasi berlangsung lobster air tawar hanya di beri pakan berupa pellet.

Selama kegiatan penelitian, lobster diberi pakan berupa pelet dan pakan tambahan berupa kentang, wortel dan ubi jalar putih. Pemberian pakan diberikan secara at satiation (pemberian pakan sekenyang-kenyangnya).

Frekuensi pemberian pakan 2 kali yaitu pukul 7.00 dan 17.00 Wib, dengan komposisi $25 \%$ diberikan pagi hari dan $75 \%$ diberikan sore hari. Pemberian persentase pakan ini disesuaikan dengan kebiasaan lobster sebagai hewan yang aktif dimalam hari (nocturnal). Pakan yang diberikan pada setiap perlakuanya itu sebanyak $3 \%$ dari biomassa lobster air tawar.

Pakan tambahan yang digunakan adalah kentang, wortel dan ubi jalar putih. Pakan tambahan kentang, wortel dan ubi jalar putih di kupas dan dicuci bersih lalu dipotong kecil-kecil berbentuk panjang seperti lidi. Pakan tambahan wortel terlebih dahulu direbus sampai pakan tenggelam, agar pada saat pemberian, pakan tidak mengapung. Tujuannya untuk memudahkan lobster air tawar mengambil makanannya. Selama pemeliharaan dilakukan pengelolaan kualitas air yang berupa pemasangan aerasi pada setiap sterofom serta penyiponan kotoran dan sisa pakan lobster air tawar yang dilakukan setiap hari sekali. 


\section{Pengambilan Data}

Pengambilan data meliputi sampling bobot, pengukuran panjang, jumlah konsumsi pakan yang dilakukan pada hari ke $0,7,14$, 21,28 . Selain itu, pengambilan data kualitas air yaitu suhu, $\mathrm{pH}$ dan $\mathrm{DO}$ dilakukan pada hari pertama dan akhir penelitian untuk mencegah terjadinya stress pada hewan uji.

\section{Parameter Penelitian}

Penghitungan pertumbuhan bobot mutlak menggunakan rumus Effendie (2007):

$$
\mathrm{W}=\mathrm{Wt}-\mathrm{Wo}
$$

Keterangan: W: Pertambahan bobot mutlak (g), Wt: Bobot lobster akhir penelitian (g), Wo: Bobot lobster awal penelitian (g).

Pertumbuhan panjang mutlak digunakan untuk menghitung pertambahan panjang lobster selama penelitian dengan menggunakan rumus:

$$
\mathrm{Lm}=\mathrm{Lt}-\mathrm{Lo}
$$

Keterangan: Lm: Pertumbuhan panjang mutlak $(\mathrm{cm})$, Lt: Panjang rata-rata akhir penelitian $(\mathrm{cm})$, Lo: Panjang rata-rata awal penelitian $(\mathrm{cm})$.

Persentase kelangsungan hidup dihitung dengan rumus sebagai berikut:

$$
\mathrm{SR}=\frac{\mathrm{Nt}}{\mathrm{N} 0} \times 100 \%
$$

Keterangan: SR:Kelangsungan Hidup (\%), Nt: Padat Tebar Akhir, No: Padat Tebar Awal.

Laju pertumbuhan harian dapat dihitung menggunakan rumus sebagai berikut:

$$
\mathrm{LPH}=\frac{\mathrm{LnWt}-\mathrm{LnW0}}{\mathrm{t}} \times 100 \%
$$

Keterangan: LPH: Laju Pertumbuhan Harian (\%), Wo: Berat Awal (g), Wt: Berat Akhir (g), $\mathrm{T}$ : Lama Pemeliharaan (hari).

Persentasi pertumbuhan berat dapat dihitung dengan rumus sebagai berikut:

$$
\mathrm{WG}=\frac{W t-W 0}{W 0} \times 100 \%
$$

Keterangan: WG: Persentasii Pertumbuhan berat (\%), Wt: Berat Akhir (g), Wo: Berat Awal (g).

Rasio konversi pakan adalah perbandingan dari jumlah pakan yang diberikan. Rumus untuk menghitung FCR adalah sebagai berikut:

$$
\mathrm{FCR}=\frac{\mathrm{F}}{(\mathrm{Wt}+\mathrm{D})-\mathrm{W} 0}
$$

Keterangan: FCR: Food convertion ratio, Wo: Bobot hewan uji pada awal penelitian, Wt: Bobot ewan uji pada akhir penelitian, D: Jumlah ikan yang mati, F: Jumlah pakan yang dikonsumsi

\section{Analisis Data}

Data hasil pengamatan dianalisa menggunakan uji $\mathrm{F}$ dan apabila setiap perlakuan memberikan perbedaan yang nyata terhadap pertumbuhan benih Lobster air tawar maka akan dilanjutkan dengan analisis komparatif dengan uji jarak berganda Duncan untuk melihat perlakuan terbaik dan hubungan antara pemberian jenis pakan alami yang berbeda terhadap pertumbuhan Lobster air tawar.

\section{HASIL DAN PEMBAHASAN}

\section{Pertambahan Bobot Mutlak (PBM)}

Tabel 1. Pertumbuhan Bobot Mutlak Cherax qudricarinatus dengan pemberian pakan tambahan yang berbeda

\begin{tabular}{cccc}
\hline Perlakuan & Berat Awal $(\mathbf{g})$ & Berat Akhir $(\mathbf{g})$ & PBM $(\mathbf{g})$ \\
\hline PL & $6,78 \pm 1,07$ & $8,27 \pm 0,32$ & $1,49 \pm 0,25^{\mathrm{b}}$ \\
PW & $6,43 \pm 0,15$ & $8,65 \pm 0,05$ & $2,21 \pm 0,06^{\mathrm{c}}$ \\
PK & $7,78 \pm 0,23$ & $9,49 \pm 0,49$ & $1,55 \pm 0,13^{\mathrm{b}}$ \\
PJ & $8,47 \pm 0,90$ & $9,41 \pm 0,74$ & $0,85 \pm 0,09^{\mathrm{a}}$ \\
\hline
\end{tabular}

Huruf yang berbeda pada kolom yang sama menunjukkan perlakuan yang berbeda nyata $(\mathrm{p}<0,05)$, nilai yang tertera merupakan nilai rata-rata dan standart error.

Tabel 1 diatas menunjukkan bahwa pertambahan bobot mutlak benih lobster air tawar pada perlakuan PW (pemberian pakan pelet + wortel) berpengaruh sangat nyata dengan perlakuan lainnya, namun perlakuan PK (pemberian pakan pelet + kentang) tidak berpengaruh nyata terhadap PL (pemberian pakan pelet). Selama pemeliharaan, lobster air 
tawar menunjukkan pertumbuhan bobot. Pertumbuhan bobot pada perlakuan PW menghasilkan pertumbuhan berat terbesar yaitu $2,21 \mathrm{~g}$, PK yaitu $1,55 \mathrm{~g}$, dan terakhir PL (pelet sebagai kontrol) yaitu 1,49 g), sedangkan pertambahan bobot terendah adalah perlakuan $\mathrm{PJ}$ (pemberian pakan pelet + ubi jalar putih) yaitu $0,85 \mathrm{~g}$. Hal ini jelas menunjukkan bahwa kandungan protein pada Pertumbuhan Panjang Mutlak (PPM) wortel dapat mengoptimalkan pertumbuhan dengan baik. hal ini sesuai dengan pendapat [6] bahwa protein pada pakan adalah kebutuhan mutlak untuk memacu pertumbuhan dan pergantian sel yang rusak. Semakin tinggi protein yang dimanfaatkan maka akan semakin baik pertumbuhan lobster air tawar.

Tabel 2. Pertumbuhan Panjang Mutlak Cherax qudricarinatus dengan pemberian pakan tambahan yang berbeda

\begin{tabular}{lccc}
\hline Perlakuan & Panjang Awal $(\mathbf{c m})$ & $\begin{array}{c}\text { Panjang Akhir } \\
(\mathbf{c m})\end{array}$ & PPM (cm) \\
\hline PL & $3,05 \pm 0,16$ & $3,41 \pm 0,17$ & $0,36 \pm 0,01^{\mathrm{a}}$ \\
PW & $3,10 \pm 0,04$ & $3,58 \pm 0,13$ & $0,33 \pm 0,01^{\mathrm{a}}$ \\
PK & $3,22 \pm 0,18$ & $3,57 \pm 0,12$ & $0,35 \pm 0,01^{\mathrm{a}}$ \\
PJ & $3,06 \pm 0,03$ & $3,50 \pm 0,04$ & $0,44 \pm 0,02^{\mathrm{b}}$ \\
\hline
\end{tabular}

Huruf yang berbeda pada kolom yang sama menunjukkan perlakuan yang berbeda nyata $(\mathrm{p}<0,05)$, nilai yang tertera merupakan nilai rata-rata dan standart error.

Hasil uji Duncan menunjukkan bahwa perlakuan PJ berbeda nyata dengan perlakuan PL, PW dan PK.Pertumbuhan panjang mutlak lobster air tawar (Cherax quadricarinatus) menunjukkan hasil adanya pertambahan panjang pada setiap minggunya di masingmasing perlakuan. Pada perlakuan PJ menunjukkan hasil pertambahan panjang tertinggi yaitu $0,44 \mathrm{~cm}$, diikuti perlakuan PL yaitu $0,36 \mathrm{~cm}$ dan perlakuan PK yaitu $0,35 \mathrm{~cm}$, sedangkan pertambahan panjang mutlak terkecil pada perlakuan PW yaitu $0,33 \mathrm{~cm}$.

Hasil penelitian ini selama 1 bulan pemeliharaan benih lobster air tawar menunjukkan adanya pertambahan panjang sebesar 0,33-0,36 cm dan pertambahan bobot sebesar 1,0-2,21 g. Hasil tersebut dapat dikatakan bahwa penelitian yang dilakukan ini mendapatkan pertambahan panjang yang lambat. Hal ini dikarenakan lobster air tawar selama pemeliharaan hanya melakukan moulting 1-2 kali dalam jangka waktu selama 30 hari, karena lobster air tawar hanya akan mengalami pertumbuhan saat sudah molting. Hal ini sesuai dengan pendapat [7] yang menyatakan bahwa pertambahan panjang tidak seiring dengan pertambahan bobot lobster, hal ini disebabkan karena pertambahan panjang hanya terjadi apabila lobster sudah melalui proses molting. Menurut [8] peran molting sangat penting bagi pertumbuhan lobster air tawar, karena lobster air tawar hanya akan bisa tumbuh setelah melalui proses molting. Hal ini diperkuat oleh [9] bahwa semakin sering lobster air tawar melakukan molting maka semakin baik pertumbuhan 


\section{Tingkat Kelangsungan Hidup}

Tabel 3. Tingkat Kelangsungan Hidup Cherax qudricarinatus dengan pemberian pakan tambahan yang berbeda

\begin{tabular}{cc}
\hline Perlakuan & Kelangsungan Hidup \\
\hline PL & $100 \pm 0^{\mathrm{b}}$ \\
PW & $100 \pm 0^{\mathrm{b}}$ \\
PK & $100 \pm 0^{\mathrm{b}}$ \\
PJ & $86,67 \pm 6,667^{\mathrm{a}}$ \\
\hline
\end{tabular}

Huruf yang berbeda pada kolom yang sama menunjukkan perlakuan yang berbeda nyata $(\mathrm{P}<0,05)$, nilai yang tertera merupakan nilai rata-rata dan standart error.

Berdasarkan tabel 3 diatas dapat dilihat bahwa pada pengamatan tingkat kelangsungan hidup lobster air tawar diperoleh hasil yang sangat baik, dimana nilai tingkat kelangsungan hidup lobster air tawar tidak kurang dari $80 \%$. Tingginya rata-rata presentase tingkat kelangsungan hidup lobster air tawar pada setiap perlakuan karena kuantitas dan kualitas pakan yang diberikan sudah memenuhi kebutuhan benih lobster air tawar sehingga pakan yang diberikan dapat dimanfaatkan secara maksimal untuk keberlangsungan hidup benih lobster air tawar.

Tingginya nilai kelangsungan hidup benih lobster air tawar dipengaruhi oleh pakan dan kualitas air yang terjaga. Hal ini diperkuat oleh [10] yang menyatakan bahwa tingginya kelulushidupan pada budidaya menunjukkan kualitas dan kuantitas pakan yang diberikan sudah cukup untuk memenuhi kebutuhan pokok. Kematian lobster air tawar selama pemeliharaan disebabkan oleh sifat kanibalisme dari lobster itu sendiri, hal ini dapat disimpulkan dari tidak lengkapnya anggota badan pada lobster air tawar yang mati. Kanibalisme terjadi pada lobster yang berukuran kecil dan lobster yang sedang mengalami proses molting. Pada saat proses molting sedang terjadi, lobster akan mengeluarkan aroma khas yang menarik perhatian lobster yang lain sehingga terjadinya kanibalisme. Hal ini diperkuat oleh [11] yang menyatakan bahwa pada saat pergantian kulit (molting) adalah saat yang paling rawan bagi lobster. Karena pada saat kulit luar terlepas, lobster akan terlihat lemah dan tidak memiliki pelindung tubuh yang akhirnya menyebabkan lobster mudah dimangsa oleh lobster lain

\section{Rasio Konversi Pakan (RKP)}

Tabel 4. Rasio Konversi Pakan Cherax qudricarinatus dengan pemberian pakan tambahan yang berbeda

\begin{tabular}{cc}
\hline .Perlakuan & Rasio Konversi Pakan \\
\hline PL & $1,74 \pm 0,09^{\mathrm{a}}$ \\
PW & $2,44 \pm 0,15^{\mathrm{b}}$ \\
PK & $4,09 \pm 0,04^{\mathrm{c}}$ \\
PJ & $5,47 \pm 0,10^{\mathrm{d}}$ \\
\hline
\end{tabular}

Huruf yang berbeda pada kolom yang sama menunjukkan perlakuan yang berbeda nyata $(\mathrm{P}<0,05)$, nilai yang tertera merupakan nilai rata-rata dan standart error.

Berdasarkan tabel 4 diatas menunjukkan bahwa perlakuan PL (pemberian pakan pelet) memiliki nilai yang paling rendah, artinya perlakuan PW (pemberian pakan pelet + wortel), PK (pemberian pakan tambahan pelet + kentang) dan PJ (pemberian pakan pelet + ubi jalar putih) tidak berpengaruh nyata terhadap rasio konversi pakan (RKP), karena semakin rendah nilai konversi pakan maka semakin baik kualitas pakan tersebut dan pakan yang diberikan dapat dimanfaatkan oleh lobster air tawar untuk pertumbuhan [12]. Rasio konversi 
pakan dihitung untuk menentukan baik atau tidaknya kualitas pakan yang diberikan pada lobster air tawar.

\section{Laju Pertumbuhan Harian (LPH)}

Tabel 5. Laju Pertumbuhan Harian Cherax qudricarinatus dengan pemberian pakan tambahan yang berbeda

\begin{tabular}{ccccccc}
\hline \multirow{2}{*}{ Perlakuan } & \multicolumn{7}{c}{ Bobot (Hari ke) } & LPH & $(\%)$ \\
\cline { 2 - 6 } & $\mathbf{0}$ & $\mathbf{7}$ & $\mathbf{1 4}$ & $\mathbf{2 1}$ & $\mathbf{2 8}$ & LPH \\
PL & $6,78 \pm 1,07$ & $0,60 \pm 1,09$ & $0,68 \pm 1,15$ & $0,51 \pm 1,15$ & $0,70 \pm 1,16$ & $0,73 \pm 0,11^{\mathrm{b}}$ \\
PW & $6,43 \pm 0,15$ & $0,98 \pm 0,44$ & $0,88 \pm 0,51$ & $0,79 \pm 0,31$ & $1,05 \pm 0,17$ & $1,05 \pm 0,03^{\mathrm{c}}$ \\
PK & $7,78 \pm 0,23$ & $0,03 \pm 0,10$ & $0,70 \pm 0,30$ & $0,64 \pm 0,24$ & $0,70 \pm 0,37$ & $0,65 \pm 0,03^{\mathrm{b}}$ \\
PJ & $8,47 \pm 0,90$ & $0,22 \pm 0,88$ & $0,16 \pm 0,85$ & $0,44 \pm 0,95$ & $0,37 \pm 0,92$ & $0,36 \pm 0,05^{\mathrm{a}}$ \\
\hline
\end{tabular}

Huruf yang berbeda pada kolom yang sama menunjukkan perlakuan yang berbeda nyata $(\mathrm{P}<0,05)$, nilai yang tertera merupakan nilai rata-rata dan standart error.

Menurut hasil uji Duncan, pertumbuhan benih lobster air tawar yang diberikan pakan tambahan yang berbeda memperoleh hasil yang amat bagus, dimana laju pertumbuhan tertinggi pada perlakuan PW yaitu $1,05 \mathrm{~g}$, diikuti PL yaitu $0,73 \mathrm{~g}$ dan PK yaitu $0,65 \mathrm{~g}$, sedangkan perlakuan terkecil pada PJ yaitu $0,36 \mathrm{~g}$.

Laju pertumbuhan sangat berkaitan dengan konsumsi pakan, lingkungan dan faktor genetis. Pemberian pakan memiliki peranan sangat penting dalam menunjang pertumbuhan lobster air tawar. [13] Protein yang sesuai dalam pakan akan dimanfaatkan secara efesien sehingga menghasilkan laju pertumbuhan yang maksimal. Hal ini diperkuat [14] bahwa protein dalam pakan yang terkonsumsi lebih banyak dimanfaatkan untuk pertumbuhan. Hal ini dipengaruhi oleh banyaknya protein pakan yang digunakan untuk menyusun jaringan tubuh yang rusak sehingga mampu mengahsilkan pertumbuhan yang lebih tinggi.

\section{Persentasi Pertumbuhan Berat}

Tabel 6. Persentase Pertumbuhan Berat Cherax qudricarinatus dengan pemberian pakan tambahan yang berbeda

\begin{tabular}{cccc}
\hline Perlakuan & Berat awal $(\mathrm{g})$ & Berat Akhir $(\mathbf{g})$ & WG $(\%)$ \\
\hline PL & $6,78 \pm 1,07$ & $8,27 \pm 0,32$ & $21,91 \pm 2,02^{\mathrm{b}}$ \\
PW & $6,43 \pm 0,15$ & $8,65 \pm 0,05$ & $34,37 \pm 0,30^{\mathrm{c}}$ \\
PK & $7,78 \pm 0,23$ & $9,49 \pm 0,49$ & $21,95 \pm 0,65^{\mathrm{b}}$ \\
PJ & $8,47 \pm 0,90$ & $9,41 \pm 0,74$ & $11,13 \pm 1,60^{\mathrm{a}}$ \\
\hline
\end{tabular}

Huruf yang berbeda pada kolom yang sama menunjukkan perlakuan yang berbeda nyata $(\mathrm{P}<0,05)$, nilai yang tertera merupakan nilai rata-rata dan standart error.

Berdasarkan tabel 6 diatas menujukkan bahwa nilai persentasi pertumbuhan berat pada perlakuan $\mathrm{PW}$ berpengaruh nyata dengan lainnya, sementara perlakuan PL dan PK tidak berpengaruh nyata. Selama pemeliharaan lobster air tawar menunjukkan pertambahan berat. Laju pertambahan berat tertinggi di perlakuan PW yaitu $34,37 \%$ dan yang terendah pada perlakuan PJ yaitu 11,13\%. Hal ini dikarenakan lobster yang digunakan selama penelitian merupakan lobster yang masih muda dan ukuran masih kecil sehingga nafsu makan lobster tinggi. [15] Lbster yang masih muda memiliki pergerakan yang aktif, sehingga membutuhkan makanan yang cukup banyak dibandingkan lobster dewasa. Semakin kecil lobster maka nafsu makan 
semakin besar dan laju pertumbuhannya akan semakin tinggi. Demikian sebaliknya semakin besar lobster maka nafsu makan akan berkurang dan laju pertumbuhannya akan semakin menurun. [16] Pakan yang tercerna dengan baik akan menghasilkan pasokan energi, energi yang berasal dari pakan inilah yang digunakan untuk aktivitas lobster sehari hari, sehingga kelebihan energi dimanfaatkan untuk pertumbuhan.

\section{Kualitas Air}

Tabel 7. Kualitas Air Media Pemeliharaan Selama Penelitian

\begin{tabular}{cccc}
\hline \multirow{2}{*}{ Perlakuan } & \multicolumn{3}{c}{ Kualitas Air } \\
\cline { 2 - 4 } & Suhu $\left({ }^{\circ} \mathbf{C}\right)$ & pH & DO \\
\hline PL & 21 & 7.15 & 4.6 \\
PW & 21 & 7.31 & 4.8 \\
PK & 22 & 7.28 & 4.6 \\
PJ & 21 & 7.26 & 4.9 \\
\hline
\end{tabular}

Berdasarkan hasil penelitian yang telah dilakukan selama pemeliharaan didapatkan hasil kualitas air yaitu suhu berkisar antara $21^{\circ} \mathrm{C}, \mathrm{pH} 7$ dan DO sebesar 4,6-4,9 mg/L. Hasil kualitas air yang diperoleh selama penelitian masih berada dalam kisaran optimum dalam pemeliharaan lobster air tawar. Hal ini diperkuat oleh pendapat [1] yang menyatakan bahwa suhu ideal untuk pemeliharaan Lobster adalah 20$30{ }^{\circ} \mathrm{C}$ Suhu air yang kurang dari $20{ }^{\circ} \mathrm{C}$ atau lebih dari $30{ }^{\circ} \mathrm{C}$ dapat menyebabkan pertumbuhan lobster air tawar terganggu, diantaranya nafsu makan berkurang [17]

Nilai pH selama pemeliharaan menunjukkan rata- rata 7 dan dapat dinyatakan sangat layak untuk kehidupan lobster air tawar. [18] menyebutkan bahwa $\mathrm{pH}$ optimal untuk pertumbuhan lobster air tawar adalah kisaran 6-8.

Hasil pengukuran oksigen terlarut (DO) selama penelitian berkisar 4-5 mg/L dan sudah memenuhi standar untuk keberlangsungan kehidupan lobster air tawar. Tinggi rendahnya nilai DO pada perairan dapat menunjukkan kualitas suatu perairan tersebut. Semakin tinggi nilai DO maka semakin baik kualitas perairan tersebut

karena air tersebut masih murni. [19] menyatakan bahwa kadar oksigen terlarut terbaik yaitu 2-4 mg/L. Kualitas air memilki peranan penting untuk menunjang keberhasilan dalam pertumbuhan lobster air tawar. [20] menambahkan, kualitas air memegang peranan yang sangat penting dalam usaha budidaya.

\section{KESIMPULAN}

Berdasarkan pengamatan yang dilakukan dapat disimpulkan bahwa Pemberian pakan tambahan berpengaruh nyata $(\mathrm{P}<0,05)$ terhadap pertambahan bobot mutlak (PBM), pertambahan panjang mutlak (PPM), tingkat kelangsungan hidup, laju pertumbuhan harian (LPH) dan persentasi pertumbuhan berat. Nilai panjang bobot mutlak (PBM), laju pertumbuhan harian $(\mathrm{LPH})$ dan laju pertumbuhan berat tertinggi di perlakuan PW yaitu sebesar $(2,21 \mathrm{~g}),(1,05 \%)$ dan $(34,37 \%)$ Nilai pertambahan panjang mutlak (PPM) terbaik di perlakuan PJ yaitu $(0,44 \mathrm{~cm})$.

\section{UCAPAN TERIMAKASIH}

Penulis mengucapkan terimakasih kepada seluruh staf Laboratorium Balai Benih Ikan (BBI) Lukup Badak, Kecamatan Pegasing, Kabupaten Aceh Tengah yang telah menyediakan alat dan bahan yang diperlukan selama pelaksanaan penelitian.

\section{DAFTAR PUSTAKA}

[1] Iskandar. Budidaya Lobster Air Tawar. Agromedia Pustaka, Jakarta.109121 hlm. 2019 
[2] Wiyanto, R dan Hartono,R. Lobster Air Tawar Pembenihan dan Pembesaran. Penebar Swadaya. Jakarta. 38 Hlm. 2006.

[3] Setiawan, C. Teknik Pembenihan dan Cara Cepat Pembesaran Lobster Air Tawar, Agromedia Pustaka, Jakarta. 49-57 hlm. 2006.

[4] Yusnaini, M. Ramli,Z. Saenong, M. Idris dan W. Iba. Analisis Faktor Internaldan Eksternal Pengembangan dan Pembenihan Lobster Air Tawar (Cherax quadricarinatus) Di Kabupaten Kolaka Timur. Jurnal Sains dan Inovasi Perikanan, (1);10-14. 2018

[5] Lim, K.C.W. Pembenihan Lobster Air Tawar Meraup Untung Dari Lahan Sempit. Agromedia Pustaka. Jakarta Pusat. 30-39 hlm. 2006.

[6] Maria GE, Mulyanto K. Materi Penyuluhan Perikanan Budidaaya Lobster Air Tawar, Jakarta: Kementrian Kelautan Perikanan. 5(1):31-4. 2011.

[7] Rihardi Irvan, Pertumbuhan Lobster Air Tawar (Cherax Quadricarinatus) pada Pemberian Pakan Dengan Frekuensi Yang Berbeda. Program Studi Budidaya Perairan, Universitas Mataram, Mataram. 8(2):109-121. 2013

[8] Ahvenharju, T. Food Intake, Growth And Social Interactions Of Signal Crayfish, Pacilastacus Leniusculus (Dana). Dissertation. Fisheries Research, Helsinki. 4(2); 153-159. 2020.

[9] Hakim, R. Penambahan Kalsium Pada Pakan Untuk Meningkatkan Frekuensi Molting Lobster Air Tawar (Cherax quadricarinatus). Laporan Penelitian. Fakultas Peternakan Perikanan. Universitas
Muhammadiyah, Malang. 4(2):153158. 2020

[10] suprayudi, m., d. Hariantodan d. Jusadi. Kecernaan pakan dan pertumbuhan udang putih (Litopenaeus vannamei) diberi pakan mengandung enzim fitase berbeda. Fakultas perikanan dan ilmu kelautan. Institut pertanian bogor. Bogor. Jurnal akuakultur indonesia. 11(2):103-108. 2012

[11] Iskandar, T. Budidaya Lobster Air Tawar. Agromedia Pustaka, Jakarta. 4(2):153-160.2020

[12] Shofura et Al. Pengaruh Penambahan PROBIOTIK-1 Pada Pakan Buatan Terhadap Efesiensi Pemanfaatan Pakan, Indonesian Journal Of Tropical Aquaculture, 1(1):10-20. 2017.

[13] Hutabarat, G. M., D Rachamawati dan Pinandoyo. Performa Pertumbuhan Benih Lobster Air Tawar (Cherax quadricarinatus) Melalui Penambahan Enzim Papain Dalam Pakan Buatan. Journal aquaculture management and technology, 4(1):10-18. 2015

[14] Ridwan Dan A.P. Idris. Analisis Kecernaan Dan Pemanfaatan Nutrien Pakan yang Mengandung Tepung Kepala Udang pada Kerapu Bebek (Cromileptes Altivelis). Jurnal Galung Tropika, 3(2):31-43. 2014.

[15] Wiyanto Dan Hartono. Lobster Air Tawar, Pembenihan dan Pembesaran. Penebar Swadaya. Jakarta. 28-36 hlm. 2013.

[16] Subandiyono dan S. Hastuti. Buku Ajar Nutrisi Ikan. Lembaga Pengembangan Dan Penjaminan Mutu. Pendidikan Universitas Diponegoro, Semarang. $233 \mathrm{Hlm}$. 2010. 
[18]Salmin. OksigenTerlarut (DO) dan Kebutuhan Oksigen (BOD) Sebagai Salah Satu Indicator Untuk Menentukan Kualitas Perairan. Jurnal Oseana, 30(3): 21 - 26. 2005

[19] Bachtiar, Y. Usaha Budidaya Lobster Air Tawar Di Rumah, Agromedia. Jakarta. 30-39 hlm. 2012

[20] Priyono, E. Alternatif Penambahan Suplemen Hayati Untuk Meningkatkan Pertumbuhan Udang Lobster Air Tawar (Cherax quadricarinatus). Tesis. Program Pascasarjana, Universitas Sebelas Maret, Surakarta, 99 Hlm. 2009. 